\title{
When speed will not get you a ticket: Speedy initial peripheral reperfusion can save patients with acute type $A$ aortic dissection and malperfusion
}

\author{
Ourania Preventza, MD, ${ }^{\mathrm{a}, \mathrm{b}}$ Corinne W. Tan, MD, ${ }^{\mathrm{a}}$ and Vicente Orozco-Sevilla, MD
}

\author{
From the ${ }^{\mathrm{a}}$ Division of Cardiothoracic Surgery, Baylor College of Medicine, Houston, Tex; and the ${ }^{\mathrm{b}}$ Department of \\ Cardiovascular Surgery, Texas Heart Institute, Houston, Tex. \\ Disclosures: Authors have nothing to disclose with regard to commercial support. \\ Received for publication Feb 22, 2018; accepted for publication Feb 22, 2018; available ahead of print March 17 , \\ 2018. \\ Address for reprints: Ourania Preventza, MD, 6770 Bertner Ave, Houston, TX 77030 (E-mail: opsmile01@aol. \\ com). \\ J Thorac Cardiovasc Surg 2018;156:469-70 \\ 0022-5223/ $\$ 36.00$ \\ Copyright (C) 2018 by The American Association for Thoracic Surgery \\ https://doi.org/10.1016/j.jtcvs.2018.02.058
}

Malperfusion syndrome occurs in as many as $30 \%$ of patients with acute type A aortic dissection. In their article in this issue of the Journal, Uchida and colleagues ${ }^{1}$ address the important and challenging subject of early reperfusion strategies to address malperfusion in such patients. The malperfusion may be cerebral, cardiac with coronary involvement, visceral, iliofemoral with lower extremity ischemia, or spinal, manifesting as paraparesis or paraplegia. Uchida and colleagues ${ }^{1}$ are to be congratulated on their excellent results, because malperfusion in patients with acute type A aortic dissection can lead to significant morbidity and mortality. ${ }^{2,3}$ Some have theorized that by taking care of the proximal dissection flap and quickly restoring flow into the true lumen, the procedures required for malperfused organs could be avoided. This may be a valid option in cases of dynamic occlusion, whereas in cases of static obstruction, intervention may be required before central aortic repair can be performed.

Various treatment algorithms ${ }^{4}$ have been advocated for acute type A aortic dissection associated with peripheral malperfusion. The timing of peripheral intervention and of surgical intervention for the dissection varies from immediate intervention of any kind to delaying surgery until after the patient's condition has stabilized.

The most lethal malperfusion syndromes are coronary, visceral, and cerebral. Uchida and colleagues ${ }^{1}$ performed emergency percutaneous coronary intervention while the operating room was being prepared. One could argue that preoperative percutaneous coronary intervention and stenting necessitate anticoagulation, which can seriously complicate a subsequent central aortic repair under circulatory arrest. In addition, early coronary reperfusion is thought to be better accomplished in the operating room. Of course, the decision ultimately depends on the surgeons' expertise, whether the team is immediately available, and other local and institutional factors that can determine which tailored approach is best.

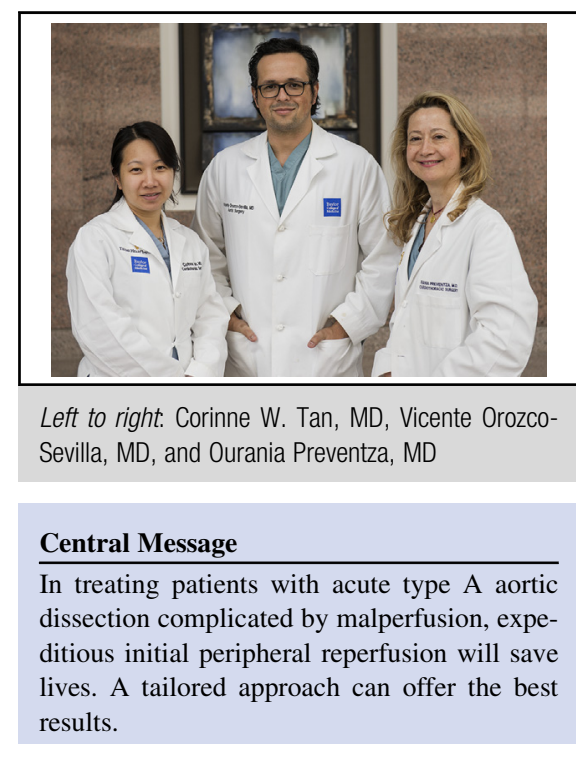

See Article page 483.

Central repair was once prohibited for comatose patients with brain malperfusion; today, however, reports suggest that early revascularization can make central repair feasible and worth trying for these patients. Uchida and colleagues followed the sensible approach of avoiding intervention only in the cases of comatose patients with a large cerebral infarction. Early direct perfusion of the carotid artery through a temporary external shunt from the femoral artery to the right common carotid artery or direct perfusion of the right common carotid artery during cardiopulmonary bypass has been advocated by various groups. ${ }^{5,6}$ The brain cannot tolerate ischemia, so early carotid reperfusion to decrease brain ischemia has been the main goal of these patients' initial treatment.

For visceral malperfusion, although not enough studies have been performed, it seems that immediate reperfusion and delay of central aortic repair until the malperfusion has resolved is the best approach. ${ }^{5}$ Uchida and colleagues ${ }^{1}$ expeditiously reperfused the superior mesenteric artery through a laparotomy, although percutaneous revascularization may be a better option if a team with knowledge of catheter-based procedures is available. For lower limb ischemia, various strategies have been advocated: an external arterial shunt to the ischemic lower extremity during cardiopulmonary bypass, as performed by the Uchida 
and colleagues ${ }^{1}$; rapid femorofemoral bypass during cooling before central repair; and central aortic repair with concomitant antegrade stent delivery in the descending thoracic aorta, as shown by others.

In examining all these different strategies for treating a potentially lethal condition, one should realize that teamwork and taking a tailored approach to each patient can offer by far the best results. Various strategies can be effective, depending on the operator's particular expertise, and collective teamwork and intelligence do matter. Reports such as that of Uchida and colleagues ${ }^{1}$ are always welcome additions to the literature.

\section{References}

1. Uchida K, Karube N, Kasama K, Minami T, Yasuda S, Goda M, et al. Early reperfusion strategy improves the outcomes of surgery for type A acute aortic dissection with malperfusion. J Thorac Cardiovasc Surg. 2018;156:483-9.
2. Goldberg JB, Lansman SL, Kai M, Tang GH, Malekan R, Spielvogel D. Malperfusion in type A dissection: consider reperfusion first. Semin Thorac Cardiovasc Surg. 2017;29:181-5.

3. Lawton JS, Moon MR, Liu J, Koerner DJ, Kulshrestha K, Damiano RJ Jr, et al. The profound impact of combined severe acidosis and malperfusion on operative mortality in the surgical treatment of type A aortic dissection. $J$ Thorac Cardiovasc Surg. 2018;155:897-904.

4. Okita Y, Ikeno Y, Yokawa K, Koda Y, Henmi S, Gotake Y, et al. Direct perfusion of the carotid artery in patients with brain malperfusion secondary to acute aortic dissection. Gen Thorac Cardiovasc Surg. December 28, 2017 [Epub ahead of print]

5. Kamman AV, Yang B, Kim KM, Williams DM, Michael Deeb G, Patel HJ. Visceral malperfusion in aortic dissection: the Michigan experience. Semin Thorac Cardiovasc Surg. 2017;29:173-8.

6. Luehr M, Etz CD, Nozdrzykowski M, Lehmkuhl L, Misfeld M, Bakhtiary F, et al. Extra-anatomic revascularization for preoperative cerebral malperfusion due to distal carotid artery occlusion in acute type A aortic dissection. Eur J Cardiothorac Surg. 2016;49:652-8; discussion 658-9.

7. Preventza O, Cervera R, Cooley DA, Bakaeen FG, Mohamed AS, Cheong BY, et al. Acute type I aortic dissection: traditional versus hybrid repair with antegrade stent delivery to the descending thoracic aorta. J Thorac Cardiovasc Surg. 2014; 148:119-25.

Access to The Journal of Thoracic and Cardiovascular Surgery Online is reserved for print subscribers!

Full-text access to The Journal of Thoracic and Cardiovascular Surgery Online is available for all print subscribers. To activate your individual online subscription, please visit The Journal of Thoracic and Cardiovascular Surgery Online, point your browser to http://www.mosby.com/itcvs, follow the prompts to activate your online access, and follow the instructions. To activate your account, you will need your subscriber account number, which you can find on your mailing label (note: the number of digits in your subscriber account number varies from 6 to 10). See the example below in which the subscriber account number has been circled:

\section{Sample mailing label}

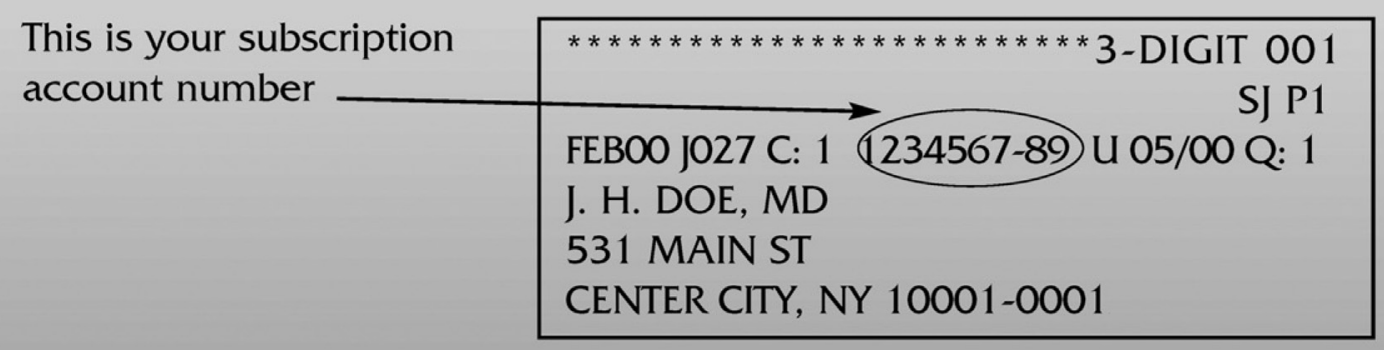

Personal subscriptions to The Journal of Thoracic and Cardiovascular Surgery Online are for individual use only and may not be transferred. Use of The Journal of Thoracic and Cardiovascular Surgery Online is subject to agreement to the terms and conditions as indicated online. 